STUDIA NORWIDIANA 37:2019

DOI: http://dx.doi.org/10.18290/sn.2019.37-15

\title{
DARIUSZ PNIEWSKI
}

\section{CZAS „CZARNEGO SŁOŃCA”}

Analizując przykłady z literatury francuskiej, angielskiej i polskiej Piotr Śniedziewski opisał rodzenie się wyobraźni katastroficznej, wyobrażeń końca świata rozumianego jako rozpad rzeczywistości, chaos, dekompozycja rzeczywistości, dystopia ${ }^{1}$. Temat to ciekawy. Autor zaproponował wiele egzemplifikacji, ale moją uwagę zwróciło zagadnienie poboczne, choć obecne w całej książce: charakterystyczne postrzeganie czasu przez romantyków. Śniedziewski dręczącą ich obawę nieuniknionego, gwałtownego końca świata, wynikającą z biograficznych doświadczeń, uczynił punktem wyjścia między innymi interpretacji powieści The Last Man Mary Shelley. Jej akcja osadzona została w latach 90. XXI w. - czasie destrukcji świata. Jak słusznie zauważył autor Czarnych słońc romanty$k o ́ w$, nie jest to porywające dzieło, choćby dlatego, że Shelley nie zaproponowała czytelnikowi wizji przeszłości, lecz w wyobraźni przeniosła bliski sobie świat w odległe czasy. Szalejąca wówczas pandemia dziesiątkuje ludzkość, a natura traci swoją równowagę, pogrążając się w mroku czarnego słońca.

Powieść Shelley, mimo że futurystyczna, to jednak jawi się współczesnemu odbiorcy jak dzieło raczej rachityczne. Tak traktuje je również autor Czarnych słońc romantyków. Wydaje mi się jednak, że może ono stanowić asumpt do „aktualizacji” myślenia o romantyzmie. Śniedziewski, konsekwentnie podążając wybraną przez siebie ścieżką metodologiczną, uznał za inspiracje do napisania katastroficznego tekstu osobiste doświadczenia Shelley: podróż z mężem Percym oraz jego śmierć. Zaczął więc swój wykład od zarysowania biograficznego tła utworu i psychologicznych pobudek na podstawie wstępu autorki do The Last Man, starając się „odtworzyć” sposób rozumienia i wykorzystania motywu „czarnego słońca” w opowieści futurystycznej w formie, lecz w istocie odnoszącej się do aktualnej sytuacji Shelley, zdeterminowanej przez wydarzenia

\footnotetext{
${ }^{1}$ P. ŚNIEDZIEWSKI, Czarne stońca romantyków, Warszawa: Wyd. Sic! 2018.
} 
z nieodległej przeszłości (,[...] zaś samą pracę nad powieścią traktuje jako terapię, coś, co pozwoli jej się pogodzić ze stratą męża [...]”)".

Obiektem swego zainteresowania Śniedziewski uczynił melancholiczną, paraliżującą trwogę przed ostatecznym końcem świata, czyli doświadczenie, a ono jest jednym z głównych tematów współczesnej humanistyki. W gąszczu definicyjnych i metodologicznych propozycji analizy doświadczenia znaleźć można przynajmniej jedną, która - jak sądzę - może pomóc w „uaktualnieniu” romantycznego sposobu mówienia o przeszłości. Frank Ankersmit, proponując swoją metodę w książce Sublime Historical Experience, uznał, że najlepsze, bo najbardziej sugestywne, jest takie budowanie narracji o minionym, w którym ujawnia się emocjonalny stosunek autora do opisywanych wydarzeń. $Z$ tego powodu określił takie podejście mianem „,neoromantycznego" ${ }^{3}$. Ankersmit nie pisał wprawdzie o melancholii, lecz o innej ambiwalentnej emocji - wzniosłości. Zanim skorzystam z jego podpowiedzi, przypomnę, że ta kategoria estetyczna bywała łączona $\mathrm{z}$ melancholią. Trzeba jednak odkreślić, że to jedna $\mathrm{z}$ możliwych relacji, bo wzniosłość pojmowano jako szczególne doświadczenie. Jego szczególność wynika z definicyjnej nieokreśloności: to stan, w którym miesza się przerażenie z przyjemnością, ekstatyczne uniesienie z (pozorną) czystością myśli. Stan ten inicjuje doznanie zmysłowe, któremu towarzyszy pobudzenie wyobraźni, a zakończeniem procesu jest próba zrozumienia go. W związku z tym, że obiekt wywołujący owo doznanie przerasta swą mocą (potęgą, siłą, wielkością, nieuchronnością) odbiorcę, podjęty przez niego wysiłek intelektualny nie może przynieść zadowalającego rezultatu. Doznanie jest jednak tak silne, a wnioski tak znaczące, że stanowi znakomity temat dla twórczości artystycznej. Jednak nieokreśloność doznania oraz brak adekwatnych środków wyrazu działają przygnębiająco, bywała więc wzniosłość kojarzona z melancholią (a dzieła wzniosłe, zwłaszcza od początku XIX w., charakteryzują: ,,negatywność”, apofatyczność, aporia). Z powodu tych właściwości Ankersmit dostrzegł we wzniosłości narzędzie wyrażenia doświadczenia przemijania, uznał, że tak pojmowana jest pokrewna uczuciu, jakie towarzyszy zapominaniu przeszłości, związanemu z koniecznością akceptacji zmian rzeczywistości. Holender przyrównał ten proces do traumy, doznania, które trwa, jest zarazem pamięcią o wydarzeniu i jego wyparciem. Tekst Shelley można uznać za zapis pracy nad okiełznaniem takiej

\footnotetext{
${ }^{2}$ Tamże, s. 35 .

${ }^{3}$ F. ANKERSMIT, Sublime Historical Experience, Stanford: Stanford University Press, 2005, s. 7; zob. E. DOMAŃSKA, Wstęp, [w:] F. ANKRESMIT, Narracja, reprezentacja, doświaczenie. Studia z teorii historiografii, red. i wstęp E. Domańska, Kraków: Universitas 2004, s. 73 .
} 
traumy (,,[..] opowieść pozwoliła jej przepracować doznaną stratę, powrócić do życia, bądź, lepiej, narodzić się ponownie [...]”, s. 36). Kolejne wersje melancholii: Théophile'a Gautiera, Gérarda de Nervala, Victora Hugo, Śniedziewski analizuje w podobny sposób - jako życie obciążone traumą. Oczywiście, nie chodzi przy tym po prostu o strach przed gwałtownym końcem, ale o niechcianą, lecz niemożliwą do zagłuszenia wizję dystopii, której będzie się świadkiem.

Podzielam opinię Autora na temat niewysokiej wartości powieści Shelley, zastanawiam się jednak, czy wpisanie w The Last Man przeniesienia własnej rzeczywistości w przyszłość (zgadzam się: nie uatrakcyjnia to fabuły) nie można by postrzegać w kontekście Ankersmitowskiej traumy przemijania. Co więcej, wydaje mi się, że jeden $\mathrm{z}$ istotnych wariantów romantycznego ,niepokoju metafizycznego”, wyrażonego motywem „czarnego słońca”, pozwala się tak opisać. Interesujący nas motyw, jak wskazał Śniedziewski, towarzyszył wizjom katastroficznym o charakterze eschatologicznym. Niezależnie od tego, czy te literackie wyobrażenia zamyka scena definitywnego końca świata, czy też okazuje się, że była ona tylko majakiem lub snem (jak np. w Mowie wypowiedzianej przez umartego Chrystusa Jean-Paula Richtera, która powraca w książce Śniedziewskiego jak leitmotiv), zasadniczy przekaz koncentruje się na sytuacji poprzedzającej ten finał. Chaos, w jakim zanurzony został podmiot, wywołuje jego melancholię: metafizyczny niepokój, stan niepewności, swoistego ubezwłasnowolnienia, zawieszenia, niemożliwej do zakończenia rozpaczy. Odpowiedzią mogło być samobójstwo na wzór młodego Wertera, ale dojrzali romantycy - to o nich pisze Śniedziewski - albo mieli dostatecznie dużo doświadczeń, by (nawet wbrew nim) cenić życie, albo rozumieli, jak interesujący materiał twórczy mają do dyspozycji, lub też - cyniczni bądź smutni (tych wybierał Autor) uznawali, że temat jest istotny. Nawet szybki przegląd dzieł literackich i plastycznych, a także zjawisk kulturowych, charakterystycznych dla romantyzmu, wskazuje, że za bardziej interesujące od definitywnych zamknięć i zakończeń uznawali stawianie swoich bohaterów w sytuacji granicznej i pozostawianie ich w takim zawieszeniu. Przypomnę choćby zakończenie Wielkiej Improwizacji, po której Konrad lewituje poza czasem i przestrzenią (prawda, niezbyt długo). Zgodnie z konwencją wzniosłości życie bohaterów takich dzieł podlega bezpośredniemu zagrożeniu, niemniej jednak - nie giną. Zawsze znajdują się na linii granicznej, bezsilni wobec niebezpieczeństwa, a jednak ciągle żywi.

Jedynym wyjątkiem, jaki przychodzi mi do głowy, jest martwy Chrystus z opowieści Richtera, ale przecież wygłasza On mowę. Jeśli dokładniej przyjrzymy się tej postaci, to okaże się wzorcowym (i jednocześnie - oryginalnym) przykładem charakterystycznego umiejscowienia romantycznych bohaterów w sytuacji (a także przestrzeni i czasie) granicznej, którą określić można jako 
„pomiędzy”, która dotyczy nie tylko umiejscawiania bohaterów dzieł wzniosłych. Lepiej oddaje sens tego pojęcia angielskie słowo „in-between”, podkreślające nie tylko znajdowanie się wewnątrz pewnej „przestrzeni”, ale także bycie jej częścią. Chrystus jest, oczywiście, pośrednikiem między Bogiem a ludźmi, lecz we śnie narratora Richterowskiej opowieści Bóg, mimo wezwań i wielu podjętych prób, nie ujawnia się swemu Synowi, co skłania tego ostatniego do konstatacji o nieistnieniu Boga. Chrystus rozważa jednak niepodzielenie się tą wiedzą z ludźmi, by przemilczeniem (w obliczu zbliżającego się końca świata) uchronić ich od utraty wiary w zbawienie i życie po śmierci. „In-between” Chrystusa jest więc jasno określone. Brak Ojca oznacza, że Chrystus nie jest Synem, nie może zatem być również odkupicielem. Nie ujawniając tej prawdy ludziom, pozostaje dla nich niepodważalną obietnicą dalszego życia. Graniczny jest moment podjęcia tej decyzji, bo zbliża się koniec świata, rzeczywistość rozpada się na oczach Chrystusa, a Jego przemilczenie jest niezmiernie ważne, bo Sądu Ostatecznego nie będzie. Chrystus znajduje się więc - zgodnie z religijną tradycją - pomiędzy transcendencją i rzeczywistością ludzka. Jednak w opowieści Richtera sam jest „przestrzenią mediacji” i pojawia się na progu czasu ostatecznego. W interesującej mnie historii znaczenie ma jeszcze jedna perspektywa czasowa. W XIXwiecznej Europie szczególną sławę zyskał tylko fragment powieści Richtera. Rozpowszechnił się on dzięki przekładowi na język francuski, zamieszczonemu w zbiorze literackich i filozoficznych nowości, zatytułowanym D’Allemagne, firmowanym nazwiskiem Madame de Staël. W owym thumaczeniu sen kończy się kosmiczną katastrofą, jednak w oryginalnym tekście Siebenkäs (1796-1797) wizja jest opowieścią w opowieści, bohater budzi się, z ulgą stwierdzając, że porządek rzeczywistości nie uległ zaburzeniu. Męczący sen miał być eschatologiczną przestrogą, zakończoną powrotem do bezpiecznej teraźniejszości gwarantowanej ponadczasowym, odwiecznym planem. We francuskim thumaczeniu bohater jest tylko jeden, to Chrystus, którego pozostawiono w przestrzeni in-between. Futurystyczna wizja Shelley również jest graniczną rzeczywistoś-cią: powtórzeniem przeszłości w przyszłości. Nowy porządek (zwłaszcza po rewolucji francuskiej) rodził obawę przed radykalnym zniszczeniem porządku poprzedniego.

Podobne obawy wywoływał tryumfalny pochód fotografii w XIX wieku. Allan Sekula streścił ówczesne wypowiedzi czarnowidzów w takim zdaniu: „Fotografia obiecuje doskonalsze opanowanie natury, jednocześnie grozi pożogą i anarchią, stanowi ładunek zdolny zmieść z powierzchni ziemi istniejący porzą- 
dek kultury”“. Wizje apokalipsy dotykającej znaną rzeczywistość nie mogły się obejść bez motywu niszczycielskiej siły słońca nawet w popularnych rymowankach, powstających krótko po oficjalnym ogłoszeniu wynalazku w 1839 r.: „O Panie Daguerre, czy świadom Pan jest / Spustoszeń, które Pan czyni? / Słońca promieniem Tamizę Pan spali, Narodową Galerię zawali”" ${ }^{5}$. Zwrotka nie mówi wprawdzie o „czarnym słońcu”, gdyż w świadomości powszechnej utrwalanie obrazów na materiałach światłoczułych kojarzyło się raczej $z$ energią, a nie $\mathrm{z}$ melancholią, niemniej jednak $\mathrm{w}$ wierności, $\mathrm{z}$ jaką fotografia odzwierciedla obiekty, widziano „zabójcę” nostalgicznych uczuć związanych z przypominaniem sobie przeszłości ${ }^{6}$. W zbiorze poetyckich wyobrażeń „czarnego słońca” Śniedziewski znalazł również takie, które łączy obie perspektywy: odnosi się do psychologii, a zarazem przypomina cytowany wyżej utwór. Poszukując źródeł inspiracji dla ujęcia tego motywu przez Victora Hugo w jednym z wersów Ust ciemności (Ce quedit la bouched'ombre, 1855), badacz przywołał opinię Paula Valéry'ego: „Niemożliwy do pomyślenia, ten n e gatyw wspaniały”. Rozszyfrowując aforyzm Valéry'ego autor książki uznał poetyckie wyobrażenie „słońca ciemności, czarnego źródła mocy" z wiersza Hugo za swoisty oksymoron. Ten z kolei poznański badacz powiązał z pojęciem negatywności, zapożyczając trafną interpretację wiersza innego twórcy:

Oksymoron jest wyrazem psychicznej udręki, bolesną wizją wszechświata, utratą światła, które od teraz staje się nieobecne. [...] Wskazując ranę zadaną przez nieobecność oraz niezaspokojone pragnienie pełni, sugeruje [...] niemożliwe do wypowiedzenia zaświaty, choć czyni to pod patronatem straty: tak oto oksymoron zyskał wymiar negatywny ${ }^{8}$.

Śniedziewski wspomniał przy tym o początkach fotografii, ale wątek po-rzucił. Proponuję przyjrzeć się jednak tej kwestii, gdyż pozwala ona dostrzec wymienione wyżej problemy: przemijania, melancholii, umiejscowienia „,in-between", z nieco innej perspektywy. Zacznę od tego, że użycie przez Valéry'ego porównania do negatywu wynikało zapewne $\mathrm{z}$ jego zainteresowania fotografią,

\footnotetext{
${ }^{4}$ A. SEKUlA, Społeczne użcia fotografii, red. K. Lewandowska, przeł. K. Pijarski, Warszawa: Zachęta. Narodowa Galeria Sztuki i Wydawnictwo Uniwersytetu Warszawskiego 2010, s. 136.

${ }^{5}$ Tamże, s. 135.

${ }^{6} \mathrm{~W}$. BENJAMIN, Charles Baudelaire, un poète lyrique à l'apogée du capitalisme, Paris: Éditions Payot 1982, s. 198.

${ }^{7}$ P. ŚNIEDZIEWSKI, Czarne słońca, s. 117.

${ }^{8}$ J.-P. Jossua, Aimer Nerval, Paris: Les Éditions du Cerf 2014, s. 219 - cyt. za: P. ŚNIEDZIEWSKI, Czarne słońca, tłum. P. Śniedziewski, s. 118.
} 
które pod koniec XIX w. zamieniło się w prawdziwą fascynację. Jak wskazuje badacz związków między literaturą francuską a fotografią w XIX w. - Paul Edwards, poetę zajmował psychologiczny problem postrzegania czasu. Dlatego jego uwagę przyciągały eksperymenty fotograficzne (zwłaszcza Étienne-Jules'a Mareya), które miały być „wizualnymi modelami” czasu ${ }^{9}$. W swojej książce Edwards subiektywnie zestawia dzieła z różnych dziedzin, aczkolwiek wskazuje katalog (nierozbudowany) podobieństw rozwiązań formalnych (to proste skojarzenia) i zbieżność intelektualnych podstaw artystycznych poszukiwań. Badacz uznał rok 1839 za orientacyjną datę pojawienia się nowego sposobu opisu świata przedstawionego; technika fotograficzna zaczęła wówczas inspirować literatów. Data to zasadna, gdyż wówczas François Arago zaprezentował wynalazek Louisa Daguerre'a i Josepha Nicéphore Niépce'a, nazwany dagerotypem, przed Francuską Akademią Nauk, ogłaszając patetycznie, że jego kraj ofiaruje ten wynalazek światu. Zainicjował w ten sposób gwałtowne zainteresowanie fotografią.

Edwards, zgodnie ze swoim podziałem, zinterpretował Panne de Maupin éophile'a Gautiera (powstała w 1836 r.) jako przykład wyobraźni, która nie dała się temu wpływowi (określił ją mianem „przed-dagerotypowej”). Napisał, że autor powieści zaprezentował pejzaże mgliste i zatopione w księżycowym świetle, w rozdz. XI i XVI, w których wprawdzie można się doszukać pewnej inspiracji fotografią, niemniej jednak ich wizualna nieklarowność i ograniczone światło sprawiają, iż bezpośrednio nie należy ich łączyćc ${ }^{10}$. To ciekawa interpretacja, ale bardziej przekonujące i przydatne wydają mi się zestawienia techniki fotograficznej z literackimi opisami kontrastów światłocieniowych, działania światła, zestawień czerni, bieli i szarości. Niebagatelne są również rozbudowane i dobrze uargumentowane rozważania na temat (jak pisze Edwards) „unieruchomienia" (l'immobilité) ruchu: planów czasowych, subiektywnego odczuwania biegu czasu ${ }^{11}$.

Czytelnikowi szukającemu poetyckich przykładów tak rozumianej „fotograficzności" obrazów w literaturze polskiej z pewnością przyjdzie na myśl $\mathrm{Nad}$ woda wielka i czysta Mickiewicza. Sprawdźmy, czy tego typu inspiracja była możliwa. Wiersz należy do grupy liryków lozańskich powstałych w latach 1839-

\footnotetext{
${ }^{9}$ P. EDWARDS, Le soileil noir. Photographie et littérature des origines au surréalisme, Rennes: Presses Universitaires ed Rennes 2008, s. 110, 113, 115. Jeden z podrozdziałów w zmienionej wersji zamieszczono [w:] TENŻE, Paul Valéry et Étienne-Jules Marey: de l'instantané à la durée. e-Bulletin des Amisde Marey et des Musées de Beaune - Villa Médicis, 2014, brak stron, https://hal.archives-ouvertes.fr/hal-01504256 [dostęp: 28.12.2018].

${ }^{10}$ TeNŻE, Le soileil noir, s. 126.

${ }^{11}$ Tamże, s. 107-118 (rozdz. VIII: „Le symbolisme et la chronographie”).
} 
1840, przekracza więc umowną cezurę wskazaną przez Edwardsa. Nie jestem pewien, czy Mickiewicz w czasie pobytu w Lozannie interesował się wciąż raczkującą fotografią, ale mogą o tym świadczyć pewne poszlaki. Jak wiemy, polski poeta wykładał na tamtejszym uniwersytecie od października 1839 roku. Spotkał się z dobrym przyjęciem nie tylko ze strony kolegów-wykładowców, ale także ważnych osób w mieście. Należał do grona znajomych Juste'a Oliviera, pisarza, poety, dziennikarza, pracownika uniwersytetu, człowieka mającego wpływ na tamtejszą elitę intelektualną i towarzyską. Tyle wiemy, dalej pozwolę sobie na rekonstrukcję. Uczniem i przyjacielem Oliviera był Charles Secrétan, prawnik i teolog, profesor uniwersytetu od 1839 do 1840 r., członek jednej z najbardziej znaczących rodzin w Lozannie. Rodzina Secretan (Charles zmienił nieznacznie pisownię nazwiska) należała do elity miejskiej, we władzach miasta od 1802 do 1842 r. zasiadało kilka osób o takim nazwisku (Charles, Victor, Charles-Frederique, Louis), dodatkowo dwie inne pełniły ważne funkcje: jeden Secretan był członkiem miejskiego nadzoru budowlanego (Samuel-Henry), kolejny - zarządu lasów (Henri). W spisie znaczących osób w mieście znalazło się jeszcze dwóch prawników (Charles-Isaac i Eduard) i jeden - jak napisano - przedstawiciel nauki $^{12}$. To Marc, który objął w 1838 r. katedrę matematyki na uniwersytecie. Był on także optykiem, od 1840 r. wspólnie z Frédérikiem Martensem i Samuelem Heerem pracowal nad tworzeniem aparatów fotograficznych i materiałów światłoczułych. Dodam, że Martens stał się znanym fotografem pejzażowym, zdarzało mu się uwieczniać między innymi Zamek Chillon nad Jeziorem Genewskim, ale - niestety - czynił to później. Podsumowując ten przegląd szwajcarskich (ale znanych znacznie szerzej, zarówno z powodu wynalazczej aktywności i zarobkowego rozpowszechniania efektów działalności, jak i publikacji, a także - po prostu - zmiany miejsca zamieszkania) pionierów fotografii mogę powiedzieć, że choć nie możemy być pewni, czy Mickiewicz interesował się nią w czasie pobytu w Lozannie, to jednak warunki po temu były sprzyjające.

W liryku Nad woda wielka i czysta nie znajdziemy motywu „czarnego słońca”, ale poeta dostrzegł w górskich szczytach „twarze czarne”, nad którymi przesuwały się „czarne obłoki”. Powtórzę, że Edwards zaproponował, by mówić o wpływie fotografii na wyobrażenia pejzażowe w literaturze, gdy sugerują one unieruchomienie, a także charakterystyczną monochromatyczność, wyraziste kontrasty światłocieniowe, szarości, a także operowanie światłem. W wierszu pojawia się nieruchoma woda i góry, a także czerń i gwałtowna jasność. Jeśli

${ }^{12}$ Lausanne à travers les âges, M. van Muyden i in., Publié par la Municipalitéde Lausanne, Librarie Rouge, Lausanne 1906, https://fr.wikisource.org/wiki/Lausanne_\%C3\% A0_travers_les_\%C3\%A2ges/Texte_entier[dostęp: 02.01.2019]. 
podążymy tropem „fotograficzności” tego utworu, to możemy uznać, że pierwsze trzy zwrotki przypominają sekwencję kolejnych kadrów, choć powtarzanie się dwóch wersów (drugi przedłużony do początku kolejnego wersu) w każdej $\mathrm{z}$ tych zwrotek wskazuje, iż ujęcie pozostaje niezmienione, jakby aparat skierowany był na taflę wody. Pośredniczy ona w percepcji otoczenia na wzór lustra lub fotografii; podobną mediacyjną funkcję pełni obserwator, jak wskazuje powtórzenie tego samego słowa: „I woda tonią przejrzystą / odbiła [...] ”, „I wszystko wiernie odbijam”. Ostatni z tych wersów znowu podsuwa skojarzenie z lustrem lub fotografią, aczkolwiek to drugi wariant wydaje się lepiej thumaczyć to wyobrażenie, ponieważ ,wierne odbicie” oznacza w tym wierszu utrwalenie obrazu, który jest także materiałem pamięci.

Nadmieniłem wyżej, że Edwards opisał fascynację Valéry’ego względnością percepcji czasu. Francuski poeta przeciwstawiał czasowi obliczanemu matematycznie „czas psychiczny i psychologiczny” i twierdził, że skoro jego bieg odczuwa się w sposób subiektywny, to stanowi on swoisty stan świadomości ${ }^{13}$. Inspirował się przy tym osiągnięciami intensywnie rozwijającej się wówczas dyscypliny naukowej - psychologii $^{14}$, w której znajdował potwierdzenie swoich intuicyjnych odczytań eksperymentalnej fotografii Mareya z lat 80. XIX w. Ten ostatni wykonywał wówczas między innymi zdjęcia ruchu ptaków. Przypominają one fotografię poklatkową, wykonaną z tak dużą częstotliwością, że zarejestrowany został (niemal) nieprzerwany ciąg zmian kształtu zwierzęcia. Edwards pisze, cytując obszernie Valéry'ego, że w tego typu fotografii fascynowało literata utrwalenie upływu czasu ${ }^{15}$, a w dziełach Mareya - przypomnę - widział „wizualne modele" tego zjawiska. Niemal w identyczny sposób zajmowali się tą kwestią także futuryści, malarze (na przykład słynny Akt schodzacy po schodach $n r 2$ z 1912 r. Marcela Duchampa; natomiast Akt opatrzony kolejnym numerem powstał w roku 1916 jako ręcznie kolorowana odbitka żelatynowo-srebrowa) i poeci, od początku drugiego dziesięciolecia XX w. Przywołanego tu przeze mnie wiersza Mickiewicza nie mam jednak zamiaru wpisywać $\mathrm{w}$ tę tradycję literacką.

Valéry snuł swoje rozważania na początku XX w., więc znacznie później, niż powstał wiersz polskiego poety, jednak wydaje mi się, że podsuwa on jeszcze jeden trop wiążący Nad woda wielka $i$ czysta z wyobraźnią fotograficzną. W utworze tym różne grupy obiektów wydają się funkcjonować w różnym cza-

\footnotetext{
${ }^{13}$ P. EDWARDS, Le soileil noir, s. 113-115.

${ }^{14}$ Zob. M. KIMURA, Le mythe du savoir : naissance et évolution de la pensée scientifique chez Paul Valéry (1880-1920), Frankfurt am Main: Peter Lang 2008, s. 242-245.

${ }^{15}$ P. EDWARDS, Le soileil noir, s. 113-115.
} 
sie. Niezmienność gór i wody, podkreślona powtórzeniami, stanowi stały punkt odniesienia zarówno w przestrzeni, jak i w czasie. Podmiot obserwuje zjawiska o agresywnym charakterze, a opisujące je określenia wskazują na szybkie (nienaturalne, tj. niezgodne z doświadczeniem) tempo ich przebiegu i zmian: „przebiegły czarne obłoki”, „błysnęło wzdłuż” (połączenie czasu z przestrzenią). Obserwator znajduje się więc między dwiema odmiennymi ,przestrzeniami czasowymi”, w trzeciej, niespiesznej, jak sugeruje powtórzenie słowa „płynąć”, pod koniec wiersza.

Śniedziewski podobnie przeczytał sonet Nervala El Desdichado: „Tu właśnie kryją się dwa zasadnicze problemy, z którymi zmierzyć się musi Nerval: pierwszym jest kwestia tożsamości (kim jest w tym wierszu ,ja”?, co odczuwa i jakie więzi łączą je ze światem?), drugim - doświadczenie czasu" "16. Autor Czarnych słońc romantyków zbadał warstwę językową tekstu, wyłuskując z niego Nervalowskie traktowanie twórczości jak azylu, a jednocześnie pola walki z dręczącą go chorobą. Śniedziewski skonstruował analizę, w której połączył perspektywę biograficzną z romantycznym problemem przemijania, a obserwacje wywiódł ze sprawdzenia czasu gramatycznego wypowiedzi zapisanych w utworze ${ }^{17}$.

Motyw „czarnego słońca” to ważny element wizji wyrażających problemy nurtujące romantycznych twórców: przemijania, podmiotowości, tożsamości, a także percepcji i sposobów jej wyrażenia. Bardzo często kwestie te splatano ze sobą, ale organizowano je wokół indywidualnego doświadczenia czasu. Odmienność czasu „odczuwanego” od ,zewnętrznego" wobec bohatera jest wyraźnie widoczna na przykład w Mowie wypowiedzianej przez umarlego Chrystusa. Niszczenie świata przebiega w szybkim tempie, a postać wypowiada swoje rozważania, jakby znajdowała się w innej - choć nieizolowanej - rzeczywistości, w której czas biegnie wolniej. „Osobista” przestrzeń bohatera mieści się „pomiędzy" (in-between) innymi, wyraźnie nakreślonymi przestrzeniami. Postać, pozostająca w takim zawieszeniu, jednocześnie określa swoją „pozycję” w odniesieniu do nich, konstruując lub weryfikując dzięki temu wyobrażenie o sobie. Ogólną motywacją jest - charakterystyczne dla romantyków - zdobywanie samoświadomości. Jak wskazuje przywołana wyżej Mowa... Richtera lub The Last Man Shelley, autorzy dzieł powstałych na początku tej epoki wracali z niedookreślonej przestrzeni in-between do znanego sobie, uporządkowanego świata (w pierwszym przypadku śniąca postać się budzi, w drugim - przyszłość jest kopią przeszłości). Różnią się one pod tym względem od prace literackich po-

\footnotetext{
${ }^{16}$ P. ŚNIEDZIEWSKI, Czarne stońca, s. $88 \mathrm{n}$.

${ }^{17}$ Tamże, s. 93-94.
} 
wstałych w okresie dojrzałego romantyzmu: te wyrażają bowiem smutną, dojrzałą, odważną akceptację nieodwracalnego przemijania.

\section{BIBLIOGRAFIA}

ANKersmit F., Narracja, reprezentacja, doświaczenie. Studia z teorii historiografii, red. i wstęp E. Domańska, Kraków: Universitas 2004.

ANKersmit F., Sublime Historical Experience, Stanford: Stanford University Press 2005.

Benjamin W., Charles Baudelaire, un poète lyrique à l'apogée du capitalisme, Paris: Éditions Payot 1982.

EDWARDS P., Le soileil noir. Photographie et littérature des origines au surréalisme, Rennes: Presses Universitaires ed Rennes, 2008.

Edwards P., Paul Valéry et Étienne-Jules Marey: de l'instantané à la durée. e-Bulletin des Amis de Marey et des Musées de Beaune - Villa Médicis, 2014 (brak stron), https://hal.archivesouvertes.fr/hal-01504256 [dostęp: 28.12.2018].

Jossua J.-P., Aimer Nerval, Paris: Les Éditions du Cerf 2014.

KIMURA M., Le mythe du savoir : naissance et évolution de la pensée scientifique chez Paul Valéry (1880 - 1920), Frankfurt am Main: Peter Lang 2008.

Lausanne à travers les âges, M. van Muyden i in., Publié par la Municipalité de Lausanne, Librarie Rouge, Lausanne 1906, https://fr.wikisource.org/wiki/Lausanne_\%C3\%A0_travers_les_\%C3 \%A2ges/Texte_entier [dostęp: 02.01.2019].

Sekula A., Społeczne użycia fotografii, red. K. Lewandowska, przeł. K. Pijarski, Warszawa: Zachęta. Narodowa Galeria Sztuki i Wydawnictwo Uniwersytetu Warszawskiego 2010.

ŚNIEDZIEWSKI P., Czarne stońca romantyków, Warszawa: Wyd. Sic! 2018.

\section{CZAS „CZARNEGO SŁOŃCA”}

\section{S t r e s z c z e n i e}

Tematem tekstu jest charakterystyczne dla romantyków literackie przedstawienie doświadczenia czasu. O czasie jako problemie rozważanym przez XIX-wiecznych twórców napomyka kilkakrotnie w swojej najnowszej książce Piotr Śniedziewski. W artykule kwestię tę zaprezentowano, wykorzystując aktualną refleksję na temat doświadczenia („historical sublime experience" Franka Ankersmita) i ustalenia dotyczące wpływu gwałtowanie rozwijającej się po 1839 r. fotografii na sposób kształtowania literackiego świata przedstawionego, a także używania fotografii jak narzędzia analizy czasu (,wizualnego modelu czasu”).

Słowa kluczowe: czas; przemijanie; doświadczenie; wzniosłość; melancholia; dagerotypia; historia fotografii; fotografia i poezja. 
THE TIME OF THE "BLACK SUN"

\section{S u m m a r y}

The text concerns the literary presentation of experiencing time that was characteristic of Romantics. In his latest book, Piotr Śniedziewski mentions time as a problem considered by $19^{\text {th }}$-century artists several times. The article presents this issue using the current reflection on the experience (Frank Ankersmit's "historical sublime experience") and the findings concerning the impact of photography that has been developing rapidly since 1839 , on the way the literary represented world is shaped, as well as the use of photography as a tool of analysing time ("the visual model of time").

Key words: time; passing; experience; solemnity; melancholy; daguerreotype; history of photography; photography and poetry.

Translated by Rafat Augustyn

DARIUSZ PNIEWSKI - doktor hab., Instytut Literatury Polskiej Uniwersytetu Mikołaja Kopernika w Toruniu; e-mail: dariusz.pniewski@umk.pl 